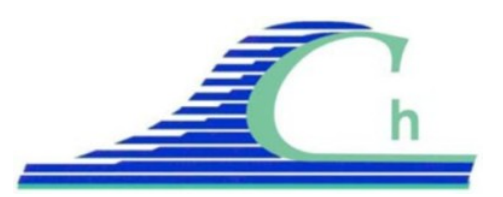

XII ${ }^{\text {ìmes }}$ Journées Nationales Génie Côtier - Génie Civil

Cherbourg, 12-14 juin 2012

DOI:10.5150/jngcgc.2012.022-B @ Editions Paralia CFL

disponible en ligne - http://www.paralia.fr - available online

\title{
SUBDUNE tool: quasi-explicit formulation of the water level along the shoreline
}

\section{Frédéric BOUCHETTE $^{1,2,5}$, François SABATIER ${ }^{2,3}$, Georgios SYLAÏOS $^{4}$, Samuel MEULE ${ }^{2,3,4}$, Jying-Yi LIOU ${ }^{6,5}$, Hugues HEURTEFEUX ${ }^{7}$, Cléa DENAMIEL ${ }^{8}$, Hwung-Hweng HWUNG ${ }^{6,5}$}

1. METOS, Forskning Center, University of Oslo, Blinder 0373 Oslo, Norway. frederic.bouchette@gmail.com

2. GLADYS / SO-LTC, OSU OREME \& Géosciences-M, CNRS/ UM2, 34095 Montpellier, France.

3. Aix Marseille Université, CEREGE UMR 6635, BP 80, 13545 Aix-En-Provence, France.

4. Department of Environmental Engineering, Democritus University of Thrace, 67100 Xanthi, Greece.

5. LIA-ADEPT (LIA CNRS/NCS 536) France/Taiwan.

6. National Cheng Kung University, No.1, University Road, Tainan City 701, Taiwan (R.O.C.).

7. Space \& Atmospheric Physics Group, Imperial College London, Prince Consort Road London, UK.

8. EID-Méditerranée, 165 av Paul Rimbaud, 31184 Montpellier, France.

\begin{abstract}
:
SUBDUNE v0.6 is a very preliminary version of an exploratory model designed to compute the sea level to the shoreline, combining the effects of various physics, from run-up to tides. It aims at providing an easy-to-use and quick way to estimate water elevation to the beach, assuming morphology is known. Combined with accurate beach data, such as LIDAR, this engineering tool may provide with end-users an efficient way to quantify submersion.
\end{abstract}

\section{Keywords:}

Sea level, Swash - Shallow water - Shoaling - Exploratory model - Shoreline - Run-up

\section{Introduction}

The quantification of an exact sea level can be tackled following two distinct points of views. One may plan to compute the sea level with an extensive use of numerical tools and nestings of simulation grids, combining most of the physics concerned. This method requires "simulation models" (MURRAY, 2003). Another way is to use "exploratory models", each of them dealing with one elementary physical process, isolated from the rest of the physics that control the sea level dynamics. Simulation and exploratory models were extensively discussed by PAOLA (2000), DE VRIEND (2001) 
and MURRAY (2003). Exploratory models arise when trying to understand peculiar or not well-known phenomena. They are much more convenient for that, as modelled physics are perfectly understood, numerical adjustements are minimized and weakly interfere with physics. Exploratory models are designed for sensitivity analyses, or quick runs. A challenge is to combine various exploratory models to provide a realistic quantification of the combined effects of several elementary processes. In this context, we shortly present the very first version of a numerical tool (SUBDUNE v0.6) that connects exploratory models designed to quantify the sea level to the shoreline.

\section{The sea level}

In the literature, the terms water level or sea level refer to distinct definitions, depending on the time and spatial scales one considers. When the topic concerns wave propagation to the coast, the water level corresponds to an approximated shape of the sea surface, including information relative to waves. In such a case, the waves are described by macro/ statistical properties $\left(\mathrm{H}_{1 / 3}, \mathrm{H}_{\mathrm{S}}, \mathrm{T}_{01}, \ldots\right)$ (e.g. FAIRBRIDGES, 1997); any graphical representation of the sea surface includes oscillations that are not observed in the field, but are representative of what occurs at a time scale of the order of a few seconds, and a spatial scale of the order of a few tens of meters (DEAN \& DALRYMPLE, 2002). When the subject is the wave breaking or the wave swash (BATTJES \& JANSSEN, 1978), the instantaneous water level must comprise all wave features, and the location of the interface between air and water is as precise as possible. However, in this case, most of the physics seaward the shoaling zone is lost; the instantaneous sea level is local, with no consideration to the influence of regional offshore processes. When the concern is for time scales of the order of hours, the sea level is a mean value that smoothes vertical variations due to swell and focusses on tides (SIMON, 2007), surges (STEETZEL, 1993; SHIBAYAMA, 2009), seiches (e.g. GROEN \& GROVES, 1962) or other possible vertical variations at a spatial scale kilometric in range. If one smoothes the time signal over a monthly/ yearly period or more, the concept of mean sea level arises (DRONKERS, 2005). Mean sea level (MSL) is a measure of the average elevation of the surface of the ocean, such as the halfway point between the mean high tide and the mean low tide, smoothing any other cyclic vertical oscillation driven by other meteorological forcings. Last, the seasonal, historical or geological sea levels refer to mean values that correspond to not so well-identified physical processes, and are quantified by indirect consequences of sea level variations: shift of paleo-beaches, location of ancient harbours, antique piers, or variation of chemical proxies in cores (WRIGHT \& SHORT, 1984). In this work, we tentatively combine these sea levels to define a realistic level at a given time along the shoreline. 


\section{XII ${ }^{\text {èmes }}$ Journées Nationales Génie Côtier - Génie Civil \\ Cherbourg, 12-14 juin 2012}

\section{SUBDUNE principle}

\subsection{Exploratory models in SUBDUNE}

Formerly, SUBDUNE is a tool that calculates sea level contributions $\eta_{\mathrm{m}}$ from mathematical expressions $\mathrm{S}_{\mathrm{m}}, \mathrm{m} \in[1 ; \mathrm{M}]$ for each physical process $\mathrm{m}$ that may contribute to the water level significantly. For a given $\mathrm{m}$ :

$\mathrm{S}_{\mathrm{m}}: \mathrm{f}_{\mathrm{m}}\left(\zeta_{\mathrm{j}}\right)=0, \mathrm{j} \in[1 ; \mathrm{N}]$

where $S_{m}$ is the exploratory model (an equation $f_{m}$ as simple as possible) for the elementary process $\mathrm{m}$, and $\left(\zeta_{\mathrm{j}}\right)$ are a limited set of $\mathrm{j}$ input parameters. From $(1)$, the water level $\eta_{\mathrm{m}}$ are then combined to define a total instantaneous sea level $\eta$. From the literature, we identify the following elementary processes (named by their exploratory model) which have a significant influence on the water level: $\left(\mathrm{S}_{1}\right)$ wave setup; $\left(\mathrm{S}_{2}\right)$ storm surge (wind effect, with possible Coriolis effect); $\left(\mathrm{S}_{3}\right)$ storm surge (regional pressure disturbance effect); $\left(\mathrm{S}_{4}\right)$ astronomical tide effect; $\left(\mathrm{S}_{5}\right)$ effects driven by climate or similar very low frequency contributions; $\left(\mathrm{S}_{6}\right)$ wave transformation and elevation changes over nearshore sand bars; $\left(\mathrm{S}_{7}\right)$ Edge waves and their effect on the elevation; $\left(\mathrm{S}_{8}\right)$ infra-gravity waves and subsequent water level modification; $\left(\mathrm{S}_{9}\right)$ wave run-up on the beach; $\left(S_{10}\right)$ effect of coastal defense structures; $\left(S_{11}\right)$ seiche and internal waves effect in protected environments; $\left(S_{12}\right)$ contribution of river discharge and other mouth processes. Practically, SUBDUNE v0.6 embeds the following elementary processes: $\mathrm{S}_{1}$, $\mathrm{S}_{2}, \mathrm{~S}_{3}, \mathrm{~S}_{4}, \mathrm{~S}_{5}, \mathrm{~S}_{9}$. Formulations from the literature give the opportunity to compute them with limited and easy-to-get information. Other contributions are not implemented yet for many reasons: (1) they have a significant influence in a too small number of forcing conditions, (2) they require too many input parameters, (3) they are not well formulated from a mathematical point of view, (4) a coastal manager may not easily decide when and where to use them. In addition, the actual version of SUBDUNE is a 2DV model: it can process water elevation along cross shore profiles; but it cannot tackle complex 2D surface objects such as piers, groins, as well as typical 2D environments (river mouths).

\subsection{Wave setup contribution $\left(\mathrm{S}_{1}\right)$}

Wave setup is "the increase of water level within the surf zone due to the transfer of wave-related momentum to the water column during wave-breaking. Wave setup has been investigated theoretically and under laboratory and field conditions, and it includes both static and dynamic components" (DEAN \& WALTON, 2009). These authors also wrote what follows. As waves approach the shoreline, they convey both energy and momentum in the wave direction. Upon breaking, the wave energy is dissipated, as it is evident from the turbulence generated; however, momentum is never dissipated but is rather transferred to the water column resulting in a slope of the water surface to balance the onshore component of the flux of momentum. Wave setup is also refered to a more general contribution of waves to the water level change, including global mass 
transport effect (not strictly relative to wave breaking). Combining these points of view, WEBER et al. (2009) demonstrate after WEBER et al. (2006):

$$
\frac{\partial \eta_{1}}{\partial x}=\frac{3 h_{0}^{1 / 2} A_{0}^{2}}{8 h^{5 / 2}}\left[\frac{d h}{d x}+\frac{2 h r}{C}+\frac{2 c_{B} h_{0}^{1 / 2} A_{0}^{2}}{3 h^{5 / 2}}\right] \exp \left(-\frac{r}{C} x\right)
$$

where: $\eta_{1}(x, t)$ the elevation with respect to a reference level, $h(x)$ the water depth along the beach profile, $\mathrm{C}$ the wave celerity, $\mathrm{r}(\mathrm{x})$ a friction factor, $\mathrm{h}_{0}$ the water depth seaward the significant shoaling zone $(\mathrm{x}=0), \mathrm{A}_{0}$ the wave amplitude seaward the significant shoaling zone $(x=0)$. SUBDUNE uses eq. (2) for the wave setup contribution to the sea level.

\subsection{Large scale contributions $\underline{S}_{2}, \underline{S}_{3}, \underline{S}_{4}, S_{2}$}

Through the misuse of language, the term "storm surge" in casual use is storm tide. It refers to the rise of water associated with the storm, plus tide, wave run-up, and freshwater flooding. When referencing storm surge height, it is important to clarify the usage, as well as the reference point. We use a strict definition of surge, that is, the effect of wind and air pressure. Long wave equations can be used to tackle the question of a wind storm blowing over bodies of water such as continental shelf (MEI, 1989), or a lake. Although the wind shear stress is usually very small, its effects when integrated over a large body of water, can be of the order of several metres $(6 \mathrm{~m}$ recorded in the Gulf of Mexico during some hurricanes (DEAN \& DALRYMPLE, 2005). We use DEAN \& DALRYMPLE (2005, Chap. 5, Eq. 5.96) to calculate wind contribution to sea level.

Regarding the regional pressure disturbance effect, the objective is to model a very long wave (wave length of the order of the vertical perturbation of the sea surface across all the low pressure area). DEAN \& DALRYMPLE (2005, p. 164) provide a simple implicit formulation, calculated in SUBDUNE with a classical Newton-Raphson technique.

Water level controlled by tide along the shoreline are significantly influenced by the shape of the coastline and the sea bottom. As a consequence, the local calculation of tide driven water level is based upon harmonic analysis of measured signal that take into account the regional setting (Details in SIMON, 2007).

The time scale of water level variations driven by climate change is of the order of $\mathrm{mm} /$ year. At the time scale of tens of years, many changes occur in the coastal environment. In particular, the mean shape of the shoreface may evolve depending upon the mean volume of sediment available (RAYNAL et al., 2009; 2010). In the same way, mean forcings (wave height, wave angle, ...) may change after climate influence (JIMENEZ \& SANCHEZ-ARCILLA, 2004). As a consequence, it is not possible to provide consistent quantification of water level to the long term, even with a very accurate physical model for the prediction of instantaneous sea level. However, one may 


\section{XII ${ }^{\text {èmes }}$ Journées Nationales Génie Côtier - Génie Civil \\ Cherbourg, 12-14 juin 2012}

decide to accept a given scenario for the long term sea level change, and apply it with additional changes of the short term contributions to the water level. In SUBDUNE v0.6, we suppose that one may want to calculate instantaneous water level in the future following these assumptions. For that reason, we introduce the possibility to add a long term contribution to the instantaneous water level, keeping in mind that input morphology may be adapted accordingly.

\subsection{Wave run-up on the beach $\left(\mathrm{S}_{9}\right)$}

Wave run-up is the maximum vertical extent of wave uprush on a beach or structure above a still/ mean water level (SORENSEN, 1997). Together with the wave setup, this contribution was the most studied (ERIKSON et al., 2005; SHIN \& COX, 2006) and details are provided below. BATTJES (1971), CERC (1984), HOLMAN (1986), NIELSEN \& HANSLOW (1991) AHRENS \& SEELIG (1996), and KOMAR (1998), on the basis of pioner works of HUNT (1959), propose various formulations for the runup, with respect to a reference elevation located in or beyond the surf zone. SYNOLAKIS (1987), MASE (1989), RUGGIERO et al. (2001) and HSIAO et al. (2008) proposed alternative formulations based on experimentation, field measurement, and adapted to intermediate/reflective sloping beaches. In the meanwhile, STOCKDON et al. (2006) made a review of run-up formulae and proposed:

$$
\begin{gathered}
\text { if } \xi_{0}<0.3, R_{2 \%}=0.043\left(H_{0} L_{0}\right)^{\frac{1}{2}} \\
\text { if } 0.3<\xi_{0}<1.25, R_{2 \%}=1.1\left(0.35 \beta_{f}\left(H_{0} L_{0}\right)^{\frac{1}{2}}+\frac{H_{0} L_{0}\left(0.563 \beta_{f}+0.004\right)^{\frac{1}{2}}}{2}\right) \\
\text { if } \xi_{0}>1.25, R_{2 \%}=0.73 \tan \beta_{f}\left(H_{0} L_{0}\right)^{\frac{1}{2}}
\end{gathered}
$$

where $\mathrm{R}_{2} \%$ the run-up for the $2 \%$ most invasive waves, $\mathrm{H}_{0}$ the deep water wave height, $\mathrm{L}_{0}$ the wave length, $\beta_{\mathrm{f}}$ the intertidal slope, and $\xi_{0}$ the Irribaren number. SUBDUNE uses ormulations in eqs (3), (4) and (5).

\subsection{How to combine contributions to the sea level quantification}

The coupling of the contributions to the sea level considered in the previous section may

be achieved by different ways. In the current version of SUBDUNE, we manage it through a very simple way. First, time scales for elementary processes $S_{m}$ are distinct enough to result in a very poor interaction through time between processes. Let us consider two elementary processes $S_{i}$ and $S_{j}$ and their contribution $\eta_{i}$ and $\eta_{j}$ to the water level. If $\eta_{\mathrm{i}}$ varies in time to a scale of the order of one hour, and if $\eta_{\mathrm{j}}$ does not vary significantly to the same time scale, the combined contribution may be written:

$\eta_{i+j}=\eta_{i}+\eta_{j}$

For example, the contributions of $\mathrm{S}_{2}$ and $\mathrm{S}_{3}$ may be easily combined after Eq. (6). 
Second, two distinct contributions to the water level may not extend to the same domain. Let consider $\mathrm{S}_{9}$, the contribution by wave run-up on the beach. This contribution has a significant effect in a very narrow band close to the shoreline. On the contrary, the contribution of the regional pressure disturbance $\mathrm{S}_{3}$ changes the water level in all the littoral domain and beyond. The regional contribution is assumed to force the localized contribution. In such a case, we have:

for $\mathrm{x} \in \Omega$

$\eta(x, t)=\eta_{9}(x, t)+\eta_{3}(x, t) \mid \Omega$

for $\mathrm{x} \notin \Omega$

$\eta(x, t)=\eta_{3}(x, t)$

where $\Omega$ is the boundary of a domain where $S_{9}$ applies. We systematically use Eqs (7) and (8) to quantify the total sea level to the shoreline.

\section{The SUBDUNE tool}

The input parameters required for the different exploratory models in SUBDUNE v0.6 are the following: (1) the mean regional air pressure disturbance, (2) the celerity (speed and direction) of the air pressure disturbance propagation, (3) the wind velocity and direction, (4) a cross-shore bottom profile, (5) the length of the continental shelf over which wind blows, (6) the water depth seaward the significant shoaling zone $(x=0),(7)$ the wave amplitude seaward the significant shoaling zone $(x=0),(8)$ the wave angle, $(9)$ a parameterization of tide features.

The core tool to compute the instantaneous water level is developed in C and GMT (tool box to compute maps and plots). For example, the water elevation can be calculated from a limited set of parameters such as $\mathrm{H}_{\mathrm{s}}=3.5 \mathrm{~m}, \mathrm{~T}_{01}=8 \mathrm{~s}, \mathrm{~h} *=10 \mathrm{~m}$ (closure water depth), $\theta_{\mathrm{w}}=0$ (wave angle), an atmospheric pressure set to $970 \mathrm{HPa}$, a tide range of less than $35 \mathrm{~cm}$ and a wind velocity $U=10 \mathrm{~km} / \mathrm{h}$ perpendicular to the shoreline. The bottom profile and the results for these conditions are displayed in figure 1.

Alternatively, a front-end written in PHP offers a web interface that may be used by any non-specialist through the web site www.soltc.org. This solution is versatile and userfriendly (figure 2). 


\section{XII ${ }^{\text {èmes }}$ Journées Nationales Génie Côtier - Génie Civil \\ Cherbourg, 12-14 juin 2012}

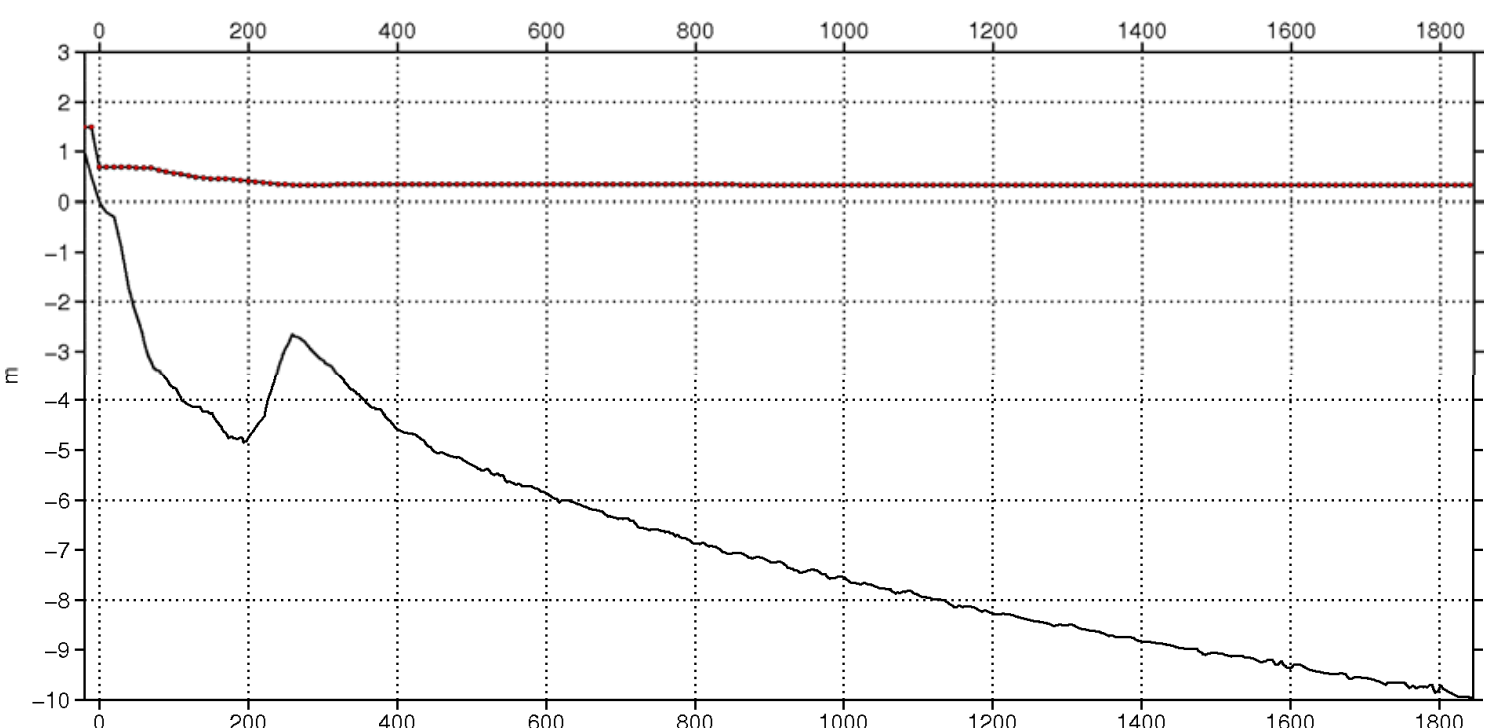

Figure 1. Example of graph calculated automatically from SUBDUNE. It displays the water level from the deeped measured point seaward to the shoreline. One will notice that water level seaward is mostly controled by wave/ wind setup. To the shoreline, runup and swash contributions dominate.
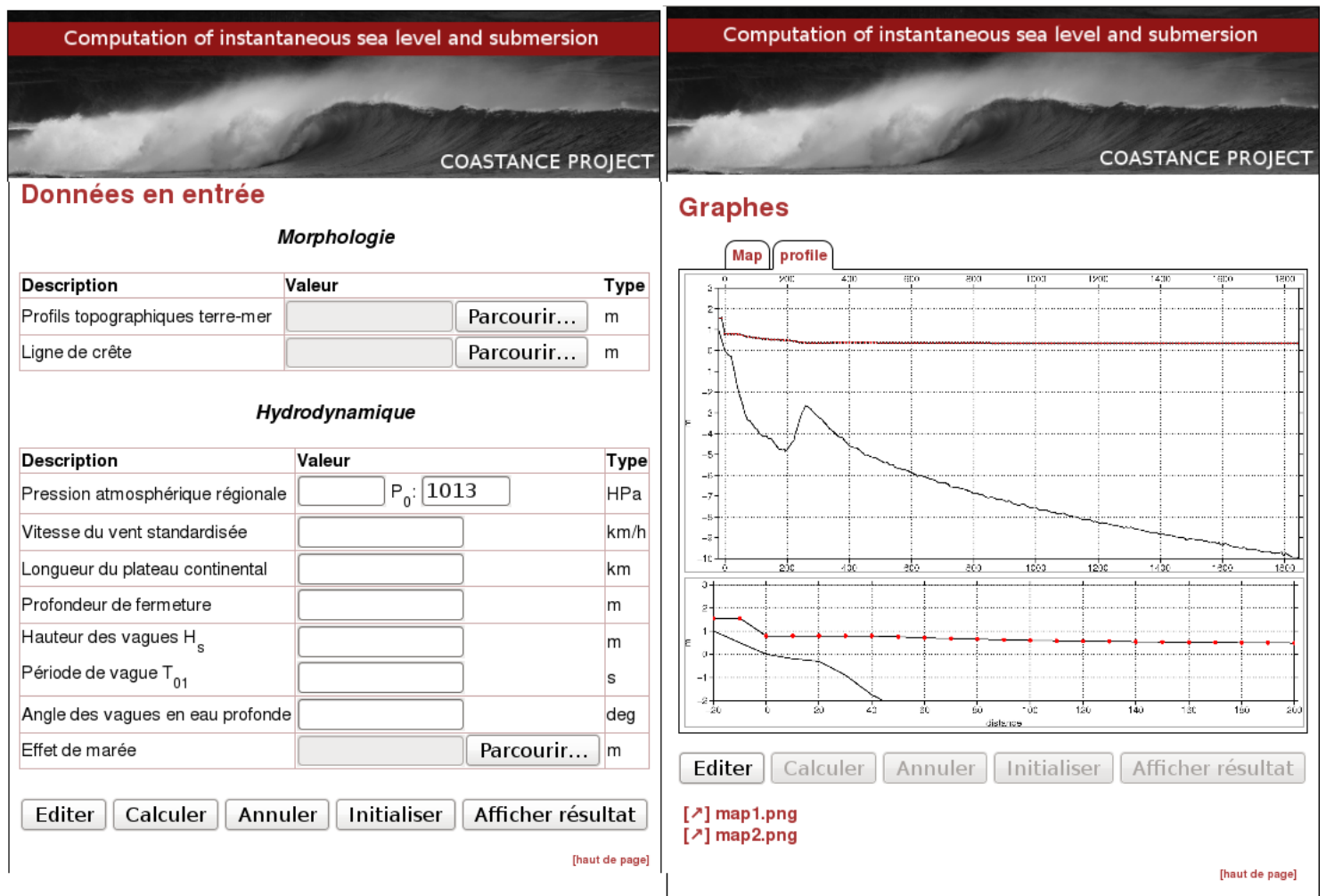

Figure 2. Left: Input page of the web tool. Right: output page of the web front-end of SUBDUNE. Link to the bottom allows to download high resolution plots of the results. 


\section{Conclusion}

SUBDUNE provides non-specialist scientists and coastal managers with a user-friendly way to compute water elevation to the shoreline, including the processes that drive it most. In its present version, SUBDUNE satisfies the needs of basic engineering works. Presently, our effort is on the validation of SUBDUNE with accurate nearshore datasets from LTC (www.soltc.org). The forthcoming developments include: (1) full 2DH version allowing the computation of water elevation against complex 2D features; (2) introduction in the list of embedded exploratory models of recent theoretical developments relative to the effect of low frequency waves on the sea level; (3) an advanced protocol to combine the various contributions to the sea level; (4) an improved front-end.

\section{Acknowledgements}

We are grateful to DREAL LR for supporting our activity for years through the coastal observatory LTC (www.soltc.org) and the GLADYS research group (www.gladyslittoral.org). We are grateful to COASTANCE (www.coastance.eu) and CG34 to have funded the early development of SUBDUNE. SUBDUNE is now developed in the framework of Taiwan-France KUNSHEN project, and is an activity of CNRS LIA ADEPT. This project is partly funded by the Prize Chercheur d'Avenir 2012 offered to F. Bouchette by Region Languedoc-Roussillon.

\section{References}

AHRENS J., SEELIG W. (1996). Wave run-up on beaches. Proceeding of the 25th Coastal Engineering Conference, American Society of Civil Engineers, pp 981-993.

BATTJES J. (1971). Run-up distributions of waves breaking on slopes. Journal of the Waterways, Harbors and Coastal Ports 92, pp 91-114.

BATTJES J., JANSSEN J. (1978). Energy loss and set-up due to breaking of random waves. In: ASCE (Ed.), Proc. 16th Int. Conf. on Coastal Eng. pp 569-587.

CERC (1984). Shore protection manual. Technical Report Vols. 1 \& 2, Coastal Engineering Research Center.

DE VRIEND H. (2001). Long-term morphological prediction. Springer, Berlin, Ch., pp 163-190.

DEAN R., DALRYMPLE R. (2002). Handbook of beach morphodynamics. Cambridge University Press, p. 480 p.

DEAN R., DALRYMPLE R. (2005). Introduction to coastal engineering. Vol. 2. World Scientific, Singapore.

DEAN R., WALTON K. (2009). Wave setup. World Scientific Pub. Co. Pte. Ltd. DRONKERS J. (2005). Dynamics of coastal systems. Vol. 25. World Scientific. doi:10.1142/9789812775252 


\section{XII ${ }^{\text {èmes }}$ Journées Nationales Génie Côtier - Génie Civil}

Cherbourg, 12-14 juin 2012

ERIKSON L., LARSON M., HANS H. (2005). Prediction of swash motion and run-up including the effects of swash interaction. Coastal Engineering 52, pp 285-302. doi:10.1016/j.coastaleng.2004.12.001

FAIRBRIDGES R. (1997). Storm, Storminess. Encyclodedia Universalis, pp 852-855. GROEN P., GROVES G. (1962). The Sea. John Wiley, Ch. 27. Surges, pp 611-643.

HOLMAN R. (1986). Extreme value statistics for wave run-up on a natural beach. Coastal Engineering 9, pp 527-544. doi:10.1016/0378-3839(86)90002-5

HSIAO S.-C., HSU T.-W., LIN T.-C., CHANG Y.-H. (2008). On the evolution and runup of breaking solitary waves on a mild sloping beach. Coastal Engineering 55, pp 975-988. doi:10.1016/j.coastaleng.2008.03.002

HUNT I. (1959). Design of seawalls and breakwaters. Journal of the Waterways and Harbors Division, Proceedings of the American Society of Civil Engineers 85, pp 123-152.

JIMENEZ J.A., SANCHEZ-ARCILLA A. (2004). A long-term (decadal scale) evolution model for microtidal barrier systems. Coastal Engineering 51, pp 749-764. doi:10.1016/j.coastaleng.2004.07.007

KOMAR P. (1998). Beaches processes and sedimentation. Prentice Hall.

MASE H. (1989). Random wave runup height on gentle slope. Journal of Waterway, Port, Coastal and Engineering 115, pp 649-661.

MEI C. (1989). The applied dynamics of ocean surface waves. Vol. 1. Word Scientific Publishing, $230 \mathrm{p}$.

MURRAY A.B. (2003). Contrasting the goals, strategies, and predictions associated with simplified numerical models and detailed simulations. In: Geophysical Union, A. (Ed.), Prediction in Geomorphology. Vol. 135. Geophysical Monograph, 15 pp 151-165. doi:10.1029/135GM11

NIELSEN P., HANSLOW D. (1991). Wave run-up distributions on natural beaches. Journal of Coastal Research, 7, pp 1139-1152.

PAOLA C. (2000). Quantitative models of sedimentary basin filling. Sedimentology 47, pp 121-178. doi:10.1046/j.1365-3091.2000.00006.x

RAYNAL O., BOUCHETTE F., CERTAIN R., SERANNE M., DEZILEAU L., SABATIER P., LOFI J., BUI XUAN HI A., BRIQUEU L., PEZARD P., TESSIER B. (2009). Control of alongshore-oriented sand spits on the dynamics of a wave-dominated coastal system, Holocene deposits, northern Gulf of Lions, France. Marine Geology, 264 (3-4), pp 242-257. doi:10.1016/j.margeo.2009.06.008

RAYNAL O., BOUCHETTE F., CERTAIN R., SABATIER P., SERANNE M., LOFI J., DEZILEAU L., BRIQUEU L., FERRER P., COURP T. (2010). Holocene evolution of languedocian lagoonal environment controlled by inherited coastal morphology (Northern Gulf of Lions, France). Bull. Soc. Géol. Franc., 181 (2), pp 211- 224. 
RUGGIERO P., KOMAR P., MCDOUGAL W.G. (2001). Wave runup, extreme water levels and the erosion of properties backing beaches. Journal of Coastal Research 17, pp 407-419.

SHIBAYAMA T. (2009). Coastal Processes. Concepts in coastal engineering and their applications in multifarious environments. Vol. 28. World Scientific Press.

SHIN O., COX D. (2006). Laboratory observations of inner surf and swash-zone hydrodynamics on a steep slope. Continental Shelf Research 26, pp 561-573. doi:10.1016/j.csr.2005.10.005

SIMON B. (2007). La marée océanique côtière. Institut Océanographique, collection Synthèse.

SORENSEN R. (1997). Basic coastal engineering. Chapman and Hall, New York.

STEETZEL H. (1993). Cross-shore transport during storm surges. Ph.D. thesis, Technical University Delft.

STOCKDON H., HOLMAN R., HOWD P., SALlENGER A. (2006). Empirical parameterization of setup, swash, and runup. Coastal Engineering 53, pp 573-588. doi:0.1016/j.coastaleng.2005.12.005

SYNOLAKIS C.E. (1987). The runup of solitary waves. Journal of Fluid Mechanics 185, pp 523-545. doi:10.1017/S002211208700329X

WEBER J.E., BROSTROM G., SAETRA O. (2006). Eulerian vs lagrangian approaches to the wave-induced transport in the upper ocean. Journal of Physical Oceanography 36(11), pp 2106-2118. doi:10.1175/JPO2951.1

WEBER J.E.H., CHRISTENSEN K., DENAMIEL C. (2009). Wave-induced set-up of the mean surface over a sloping beach. Continental Shelf Research 29, pp 1448-1453. doi:10.1016/j.csr.2009.03.010

WRIGHT L., SHORT A. (1984). Morphodynamic variability of surf zones and beaches: A synthesis. Marine Geology 56, pp 93-118. doi:10.1016/0025-3227(84)90008-2 